\title{
Using routine emergency department data for syndromic surveillance of acute respiratory illness before and during the COVID-19 pandemic in Germany, week 10-2017 and 10-2021
}

Authors: T. Sonia Boender ${ }^{* 1}$, Wei Cai ${ }^{1}$, Madlen Schranz ${ }^{1}$, Theresa Kocher ${ }^{1,2}$, Birte Wagner ${ }^{1}$, Alexander Ullrich ${ }^{1}$, Silke Buda ${ }^{1}$, Rebecca Zöllner ${ }^{3}$, Felix Greiner ${ }^{4,5}$, Michaela Diercke ${ }^{1}$, Linus Grabenhenrich ${ }^{2}$

Affiliations:

1) Robert Koch Institute, Department for Infectious Disease Epidemiology, Berlin, Germany

2) Robert Koch Institute, Department for Methodology and Research Infrastructure, Berlin, Germany

3) Health Protection Authority, Frankfurt am Main, Germany

4) Department of Trauma Surgery, Otto von Guericke University Magdeburg, Magdeburg, Germany

5) AKTIN - Emergency Department Data Registry, Magdeburg/Aachen, Germany Corresponding author: Dr Sonia Boender, BoenderS@rki.de

Key words: Public Health Surveillance; COVID-19; Respiratory Tract Infections; Emergency Service, Hospital

Word count: 244 abstract; 3,110 main body; 41 references;

Tables: 1 main, 1 supplementary

Figures: 5 main, 4 supplementary

\section{Abstract}

Introduction: To better assess the epidemiological situation of acute respiratory illness in Germany over time, we used emergency department data for syndromic surveillance before and during the COVID-19 pandemic.

Methods: We included routine attendance data from emergency departments who continuously transferred data between week 10-2017 and 10-2021, with ICD-10 codes available for $>75 \%$ of the attendances. Case definitions for acute respiratory illness (ARI), severe ARI (SARI), influenza-like illness (ILI), respiratory syncytial virus disease (RSV) and Coronavirus disease 2019 (COVID-19) were based on a combination of ICD-10 codes, and/or chief complaints, sometimes combined with information on hospitalisation and age.

Results: We included 1,372,958 attendances from eight emergency departments. The number of attendances dropped in March 2020, increased during summer, and declined again during the resurge of COVID-19 cases in autumn and winter of 2020/2021. A pattern of seasonality of acute respiratory infections could be observed. By using different case definitions (i.e. for ARI, SARI, ILI, RSV) both the annual influenza seasons in the years 2017-2020 and the dynamics of the COVID-19 pandemic in 2020-2021 were apparent. The absence of a flu season during the fall and winter of 2020/2021 was visible, in parallel to the resurge of COVID-19 cases. The proportion of SARI among ARI cases peaked in April-May 2020 and November 2020-January 2021.

Conclusion: Syndromic surveillance using routine emergency department data has the potential to monitor the trends, timing, duration, magnitude and severity of illness caused by respiratory viruses, including both influenza and SARS-CoV-2. 
medRxiv preprint doi: https://doi.org/10.1101/2021.08.19.21262303; this version posted August 21, 2021. The copyright holder for this preprint (which was not certified by peer review) is the author/funder, who has granted medRxiv a license to display the preprint in perpetuity.

It is made available under a CC-BY 4.0 International license .

\section{Introduction}

The response to the Coronavirus disease 2019 (COVID-19) pandemic expanded the need for timely information on acute respiratory illness on the population level, to trigger public health action, and support healthcare planning. Therefore, robust surveillance systems of respiratory illnesses are essential to monitor the burden of disease, and therewith inform public health to take appropriate and timely measures.

In Germany, acute respiratory illnesses (ARI) are monitored with syndromic surveillance systems at several levels of disease severity: internet-based syndromic monitoring of ARI in the general population (GrippeWeb, "FluWeb")(1); sentinel surveillance of ARI consultations in primary care, including virological surveillance (Influenza Working Group(2)) and sentinel surveillance of severe acute respiratory illnesses (SARI) among hospitalised patients using ICD-10 diagnostic codes (ICOSARI)(3). In addition, defined respiratory diseases as COVID-19 and influenza are monitored through mandatory notifications by clinicians and laboratories, within the framework of the Protection against Infection Act.

The effects of the COVID-19 pandemic, as well as the associated non-pharmaceutical interventions (NPIs) to contain the spread of the virus, have affected the transmission of not only seasonal influenza, but also other respiratory viruses in Germany $(5,6)$. These changes in the epidemiological situation affect routine surveillance systems for monitoring the epidemiology and virology of respiratory illnesses (7). Therefore, further investigation of the impact on population health, as well as the healthcare system is required.

The availability of electronically collected routine medical data, such as emergency department data, allows for an extended approach in applied epidemiology and public health surveillance (8). Syndromic surveillance using routine emergency department data can be a fast approach to report and detect changes in healthcare utilization, without creating an additional administrative burden. In the United Kingdom (9), France (10) and other countries, syndromic surveillance systems based on emergency department data have been established $(11,12)$, and have previously provided timely public health insight at extraordinary times such as extreme weather events (13) or mass gatherings (e.g. the Olympic Games in 2012 (14)), as well as during the COVID-19 pandemic (15).

Previous analyses of emergency department data in Germany successfully detected syndromes to monitor unspecific gastrointestinal infections, including their seasonal fluctuation (16), as well 
medRxiv preprint doi: https://doi.org/10.1101/2021.08.19.21262303; this version posted August 21, 2021. The copyright holder for this preprint (which was not certified by peer review) is the author/funder, who has granted medRxiv a license to display the preprint in perpetuity.

It is made available under a CC-BY 4.0 International license .

made a first description of ARI cases (17). Since end of June 2020, the weekly Emergency Department Situation Report presents data from the routine documentation of up to 21 selected emergency departments in Germany (18). These reports showed that in parallel to the COVID-19 pandemic and the associated NPIs starting mid-March 2020, attendances dropped, and partially increased again over summer (19). During the resurge of COVID-19 cases and implementation of NPIs during the fall and winter of 2020-2021, the number of attendances decreased again to about one quarter below the 2019 average, and remained below 2019 average until the time of writing (April 2021) (18).

We aimed to describe emergency department attendances for acute respiratory illness in Germany over time, for the purpose of the development and implementation of syndromic surveillance. Furthermore, we explore the impact of the COVID-19 pandemic, and its associated NPIs, on these presentations of acute respiratory illness.

\section{Methods}

\section{$\underline{\text { Study design }}$}

We used routinely available emergency department data as a basis, to describe presentations of $A R I$ in emergency departments in Germany for syndromic surveillance. Following a process of data curation, quality management and exploration, and defining syndromic case definitions, we described emergency department attendances over time to provide insight into presentation for acute respiratory illness. In addition, the impact of the COVID-19 pandemic on these trends was further explored.

\section{$\underline{\text { Setting }}$}

Data used in this analysis was provided through two networks of German emergency departments which continuously transfer anonymized routine health data to the Robert Koch Institute (RKI, Germany's national public health institute), to explore their use for surveillance: the AKTIN Emergency Department Data Registry (20) and the ESEG-project ("Erkennung und Steurung Epidemischer Gefahrenlagen"; translation: detection and control of epidemic situations http://www.rki.de/eseg). Emergency departments participate and share data on a voluntary basis. At the RKI, using the NoKeDa (NotaufnahmeKernDatensatz) data model (21), these routine health data from the different sources are merged and processed, when the date of visit, age, and sex were available. Observations were recorded by visit (attendance) and not by person; multiple visits by the same person cannot be linked. 
medRxiv preprint doi: https://doi.org/10.1101/2021.08.19.21262303; this version posted August 21, 2021. The copyright holder for this preprint (which was not certified by peer review) is the author/funder, who has granted medRxiv a license to display the preprint in perpetuity.

It is made available under a CC-BY 4.0 International license.

\section{Study population}

Emergency attendance data was exported from the RKI server on 13 April 2021, using SUMODB Release 3.0.3 (database population). In addition to the database release, data quality summary reports were generated, including information on completeness of attendances and variables. The data availability and quality could be assessed, based on the descriptive statistics and data visualisation of data quality summary. For the purpose of this work, a subset of emergency departments was included (study population): departments who continuously transferred attendance data (at least one admission per day) for the period of 6 March 2017 (week 10-2017) up to and including 13 March 2021 (week 10-2021), with ICD-10 diagnostic codes for $>75 \%$ of the attendances.

\section{Data protection and ethics}

In AKTIN and ESEG, individual patient consent is not provided for the context of the emergency situation and the technical and organizational measures provided. The AKTIN-register received medical ethical approval from the Ethics Committee of the Otto von Guericke University Magdeburg, Medical Faculty (160/15) (20). The AKTIN scientific board approved regular/daily data query and transmission to RKI (Project-ID 2019-003). Due to the anonymized nature of the data, an ethical approval was not necessary for ESEG data, as disclosed by the ethics committee of the physician's chamber Hesse. The data were transferred anonymously. The data model uses a minimal set of data points, or categorisation of specific data elements (e.g. age in years and groups, instead of date of birth), which ensures personal data protection, and defines an approved list of variables. The data protection officer of the RKI has approved the use of anonymized casebased emergency department data using the NoKeDa model for research purposes (BDS/ISB, 09-01-2019).

\section{$\underline{\text { Variables }}$}

The following variables were included for analysis: emergency department/hospital, age-group (0-2 years, 3-4 years, followed by 5-year groups, and 80+ years), sex (male/female/other), triage (codes 1 to 5, higher code meaning less urgent), diagnosis (ICD-10 codes, when labelled confirmed/suspected), chief complaints (according to the Canadian Emergency Department Information System - Presenting Complaint List [CEDIS-PCL](22) or Manchester Triage System [MTS] (23)), referral, mode of transport, disposition (e.g. hospital admission) and isolation. 
medRxiv preprint doi: https://doi.org/10.1101/2021.08.19.21262303; this version posted August 21, 2021. The copyright holder for this preprint (which was not certified by peer review) is the author/funder, who has granted medRxiv a license to display the preprint in perpetuity.

It is made available under a CC-BY 4.0 International license .

Potential missing data refers to the absence of documentation; all data are based on routine emergency care at the respective sites, based on routine documentation practices.

$\underline{\text { Case definitions }}$

We defined a set of case definitions in agreement with the established syndromic surveillance systems of acute respiratory infections at RKI and based on (inter)national standards $(24,25)$. Case definitions were based on a combination of ICD-10 diagnostic codes, or chief complaints, sometimes combined with disposition and age. Case criteria and case classifications (i.e. probable, confirmed) for acute respiratory illness (ARI), severe acute respiratory illness (SARI), influenza-like illness (ILI), respiratory syncytial virus (RSV) and Coronavirus disease 2019 (COVID-19) are summarised in Supplemental Table 1. Combined case definitions were used for the primary analysis; i.e. cases of ILI, RSV and COVID-19 were either probable and/or confirmed.

\section{Statistical analysis}

Attendances and cases were analysed as aggregated counts by week. Weekly numbers of all cases that met the case definitions (see above and Supplemental Table 1) were plotted as absolute counts, as well as proportions of cases per 1,000 attendances to adjust for fluctuations in attendances (i.e. a change in the denominator) over time. Cases of ARI and SARI were explored as individual indicators, as well as through calculating the proportion of severe cases (\%SARI/ARI). Probable and confirmed cases of ILI, RSV-Disease and COVID-19 were explored as separate and combined overall case numbers (probable + confirmed cases).

The number of weekly attendances were described and summarised for the period before and during the COVID-19 pandemic: before/after 2 March 2020 (week 10-2020), and the different pandemic phases (26). Because the number of weekly attendances were not normally distributed, Wilcoxon rank sum test was used for simple comparisons of the distribution of weekly cases per 1,000 attendances before and during the pandemic. Next, time series were decomposed to visually investigate the seasonality and trend over time; a decomposition of the COVID-19 time series of one year was not possible because the series was too short (less than two periods).

Data were analysed the data using $\mathrm{R}$ statistical software, using the tidyverse, $x t s$ and zoo packages (27). The aggregated data of the attendances and cases (ARI, SARI, ILI, RSV, COVID19) by week used for the analysis, are provided with this manuscript. 
medRxiv preprint doi: https://doi.org/10.1101/2021.08.19.21262303; this version posted August 21, 2021. The copyright holder for this preprint (which was not certified by peer review) is the author/funder, who has granted medRxiv a license to display the preprint in perpetuity.

It is made available under a CC-BY 4.0 International license .

\section{Results}

\section{Study population}

Data from eight emergency departments that transferred attendance data between 6 March 2017 up to and including 7 March 2021 with ICD-10 diagnostic codes for $>75 \%$ of the attendances, were included in this study. Consequently, the study population included data of 1,372,958 attendances from 6 March 2017 (week 10-2017) up to and including 13 March 2021 (week 102021) (Table 1). The included departments provided comprehensive (5 departments) and extended (3 departments) emergency care in seven federal states of Germany (BadenWürttemberg, Bavaria, Berlin, Brandenburg, Hesse, Lower Saxony, Saxony).

\section{Emergency department attendances}

The general characteristics of the emergency department attendances are summarized in Table 1 (Table 1). The overall sex (52\% female) and age (6\% under 2 years, $8 \% 3-9$ years; $8 \% 10-19$ years; $17 \%$ 20-39 years; 25\% $40-59$ years; $21 \% 60-79$ years; $15 \% 80+$ years) distributions remained similar over the full observation period.

Over time, the absolute number of weekly emergency department attendances dropped significantly during the first and second wave of the COVID-19 pandemic in Germany (Figure 1). The median number of attendances per week dropped from 6,886 (interquartile range [IQR]: $6,733-7,104$ ) before the pandemic, to 4,741 (IQR: $4,498-5,124 ; P<.001$ ), during the first phase of the pandemic. Following a recovery phase approaching pre-pandemic attendance rates (median 6,133; IQR: 6,010 - 6,202; $P<.001$ ) during summer, the weekly attendances declined again to 4,950 (IQR: 4,512-5,212; $P<.001$ ) during the second wave during autumn and winter of 2020/2021. The weekly attendances differed when comparing the respective phases to the prepandemic period, as summarised in Supplemental Figure 1. The highest number of 8,412 attendances per week was counted in week 09/2018, and the lowest number of 4,096 attendances per week was counted in week 12/2020.

Cases of ARI, SARI, ILI, RSV-disease and COVID-19 over time

During the full, four-year observation period, seasonal patterns were visible for ARI, SARI, ILI, and RSV-disease cases per week, per 1,000 attendees (Figure 2), as well as per absolute weekly case counts (Supplemental Figure 2). Seasonality of ARI, SARI, ILI, and RSV-disease was confirmed by the decomposed time series analysis (Figure $\mathbf{3}$ ). 
medRxiv preprint doi: https://doi.org/10.1101/2021.08.19.21262303; this version posted August 21, 2021. The copyright holder for this preprint (which was not certified by peer review) is the author/funder, who has granted medRxiv a license to display the preprint in perpetuity.

It is made available under a CC-BY 4.0 International license .

In the winter of 2020/2021, both the absolute and relative ARI case counts were lower than in previous years, and showed a downward trend (Figure 2a and 3a). Conversely, the trend of SARI cases remained fairly stable over time, with a small downward trend in the final months of winter (Figure $\mathbf{2 b}$ and $\mathbf{3 b}$ ). This pattern was also visible when assessing the proportion of severe and hospitalised ARI cases (i.e. SARI cases) among ARI cases (Figure 4). The proportion of SARI cases among ARI cases fluctuated around a median of 6.9\% (IQR: 5.3-8.3), was lower in the year 2017 (median 4.7\% [IQR: 3.4-6.2]), fairly stable in the years 2018 (6.6\% [IQR: 5.1-8.0]) and 2019 (7.4\% [IQR: 6.4-8.4]). The proportion of SARI cases among ARI cases occasionally exceeded $10 \%$, but was only observed in single weeks during pre-pandemic times: week 18/2017, week 30/2018, week 37/2018; week 8/2019, week 20/2019, and week 37/2019. The proportion of SARI cases among ARI cases peaked twice for five subsequent weeks in a row: week 15/2020 to $19 / 2020$ with a peak at week $18 / 2020(17.1 \%)$ and week $48 / 2020$ to week 2/2021 with a peak at week 53/2020 (14.2\%), as displayed in Figure 4.

Seasonality of ILI and RSV cases remained visible (Figure $\mathbf{2 c - d}$ and $\mathbf{3 c - d}$ ), despite a strong decrease in cases and attendees after March 2020. In parallel, COVID-19 cases were recorded from March 2020 onwards (Figure 5). Visual inspection of COVID-19 cases showed two periods of increased case numbers, despite the drop of overall attendances, during April-May of 2020 and a resurge of cases starting in October 2020, which was decreased again at the end of the observation period (March 2021). Overall, 17\% of COVID-19 cases were also cases of SARI (all COVID-19 cases are by definition ARI cases). Of note, weekly ILI, RSV and COVID-19 cases are plotted by probable and possible case classifications, as well as the combined case definition, in

\section{Supplemental Figure 4.}

\section{Discussion}

This descriptive study indicates proof of principle for syndromic surveillance of acute respiratory illness in emergency departments in Germany. Based on a selection of eight departments by voluntary participation, a clear pattern of seasonality respiratory illness (i.e. ARI, SARI, ILI and RSV-disease) could be observed. In addition, both the annual influenza seasons in the years 2017-2020 and the dynamics of the COVID-19 pandemic in 2020-2021 were apparent. In the winter of 2017/2018, a large peak of attendances due to ARI was visible in the emergency departments, compared to the 2018/2019 and 2019/2020 flu waves, which is consistent with the severity of the three influenza seasons observed in the other syndromic surveillance systems. Of note, the abrupt and early end of the $2019 / 2020$ flu wave could be visually identified, as described 
medRxiv preprint doi: https://doi.org/10.1101/2021.08.19.21262303; this version posted August 21, 2021. The copyright holder for this preprint (which was not certified by peer review) is the author/funder, who has granted medRxiv a license to display the preprint in perpetuity.

It is made available under a CC-BY 4.0 International license .

based on sentinel surveillance in Germany (28), as well as in Denmark, Norway and Sweden (29),. The striking absence of a flu season in $2020 / 2021(5,30)$, was also visible, in parallel to the resurge of COVID-19 cases during the fall and winter in 2020/2021. In 2020 and the beginning of 2021 , the proportion of SARI cases among ARI cases peaked twice for five subsequent weeks in April-May 2020 and November 2020-January 2021, which was the same time the first wave and resurge of COVID-19 cases peaked in Germany (31). The reduction in ILI and RSV cases during the pandemic period could, at least in part, be explained by the influence of NPIs on overall disease transmission, as observed by other surveillance systems in Germany $(5,6)$, and internationally (32).

Overall emergency department attendances dropped substantially following the start of the COVID-19 pandemic in March 2020, increased during summer, and declined again during the resurge of the pandemic during the autumn and winter of 2020/2021. The shift in attendances required a baseline adjustment for case reporting (change in denominator), by standardising the case count per 1,000 attendances. This reduction in attendances could have been partially due to the advisories to reduce physical contact with healthcare services, and to use telephone services instead (at least before visiting), when possible. This observation fits the overall reduction in hospitalisation as reported by other German hospitals $(33,34)$. In addition, a reluctance to visit health care facilities due to a fear to be exposed to SARS-CoV-2 (35), could also be a reason for a reduction in emergency department attendances. Similar trends were observed in emergency departments in other countries, including the UK (36) and USA (37).

The findings of this study should be interpreted taking the following limitations into account. First, the selected data are a convenience sample and are not representative for emergency departments in Germany as a whole. Differences on the level of individual departments, as well as differences between emergency departments, played a limited role in the analysis and interpretation. This study aimed to explore the possibility and feasibility to use these routine data for public health surveillance. In addition, structural changes at the department, including active interreference with patient flows with respiratory complaints, could have affected reported attendances and case counts. To fully understand trends in the data, being it due to a change in infection dynamics, healthcare seeking behaviour, the COVID-19 pandemic and NPIs, or structural changes at the emergency department, more information is needed. This type of investigation is, however, beyond the scope of this work. The strength of the current approach of passive surveillance using routine documentation has its own advantages being fast (timely reporting) without creating an additional burden on the healthcare workers. Furthermore, case 
medRxiv preprint doi: https://doi.org/10.1101/2021.08.19.21262303; this version posted August 21, 2021. The copyright holder for this preprint (which was not certified by peer review) is the author/funder, who has granted medRxiv a license to display the preprint in perpetuity.

It is made available under a CC-BY 4.0 International license .

definitions were based on routine documentation, designed for triage and clinical documentation in the emergency department, not designed for surveillance purposes. The syndromic case definitions heavily rely on clinical presentation, and laboratory diagnosis is often not available, or not foreseen. Shortness of breath, for example, may be a cardiac symptom as well, and is not always caused by a respiratory pathogen (38). Furthermore, information on hospitalisation (disposition), a key variable for SARI cases, was not always available, leading to potential underreporting of SARI cases. In addition, ICD-10 codes for COVID-19 diagnosis were not available from the beginning of the pandemic, leading to underreporting of the true number of cases.

Moving forward, the current ongoing, systematic collection, analysis, interpretation, and dissemination of emergency department data for use in public health action, needs to be evaluated, to make targeted recommendations to improve quality, efficiency, and usefulness of the system (39). Triangulation of data sources and formal comparison with established surveillance systems, including COVID-19 case notifications (4), and other syndromic and virological surveillance systems for acute respiratory infections $(1,3)$, will help to address underascertainment, to understand changes in consultation behaviour during public health emergencies and improve interpretation of the data.

The COVID-19 pandemic poses a new challenge for syndromic surveillance, adding an additional respiratory pathogen to the set of illnesses under monitoring and surveillance. Syndromic surveillance in emergency departments can help provide oversight of the healthcare utilisation, independent of the pathogen, for overall public health surveillance and healthcare monitoring (40). Moving forward, increased COVID-19 vaccination roll-out and subsequent (de-escalation of) NPIs, will have effects on circulation of other respiratory viruses as well. In the near future, this type of almost real-time syndromic surveillance can help to timely inform public health decision making, moving forward in the next phases of the pandemic.

The current analysis of four years of emergency department data identified syndromic cases of (severe) acute respiratory illness, and could differentiate between ILI, RSV and COVID-19 cases, which should be further investigated. Clear patterns of seasonality and trends over time were identified, for all case definitions, in line with findings reported from established ARI, SARI, ILI and virological surveillance systems (41). Syndromic surveillance of ARI and SARI in the emergency department could contribute to the overall burden estimates of acute respiratory infections in the upper and lower respiratory tract. Syndromic surveillance using routine emergency department 
medRxiv preprint doi: https://doi.org/10.1101/2021.08.19.21262303; this version posted August 21, 2021. The copyright holder for this preprint (which was not certified by peer review) is the author/funder, who has granted medRxiv a license to display the preprint in perpetuity.

It is made available under a CC-BY 4.0 International license .

data has the potential to complement established indicator based, syndromic and virological surveillance systems used to monitor the timing, duration, magnitude and severity of epidemics caused by respiratory viruses, including RSV, influenza virus and SARS-CoV-2.

\section{References}

1. Bayer C, Remschmidt C, an der Heiden M, Tolksdorf K, Herzhoff M, Kaersten S, et al. Internet-based syndromic monitoring of acute respiratory illness in the general population of Germany, weeks 35/2011 to 34/2012. Euro Surveill. 2014;19(4).

2. Koch-Institut R. Bericht zur Epidemiologie der Influenza in Deutschland Saison 2018/19. Robert Koch-Institut; 2019.

3. Buda S, Tolksdorf K, Schuler E, Kuhlen R, Haas W. Establishing an ICD-10 code based SARI-surveillance in Germany - description of the system and first results from five recent influenza seasons. BMC Public Health. 2017;17(1):612.

4. Gesetz zur Verhütung und Bekämpfung von Infektionskrankheiten beim Menschen (Infektionsschutzgesetz - IfSG), (2000).

5. Oh D-Y, Buda S, Biere B, Reiche J, Schlosser F, Duwe S, et al. Trends in respiratory virus circulation following COVID-19-targeted nonharmaceutical interventions in Germany, January September 2020: an analysis of national surveillance data. The Lancet Regional Health - Europe. 2021 ;Accepted for publication.

6. Ullrich A, Schranz M, Rexroth U, Hamouda O, Schaade L, Diercke M, et al. Impact of COVID-19 pandemic and associated non-pharmaceutical interventions on other notifiable infectious diseases in Germany: an analysis of national surveillance data during week 1-2016 week 32-2020. The Lancet Regional Health - Europe. 2021;Accepted for publication.

7. WHO. Interpreting influenza surveillance data in the context of the COVID-19 pandemic. Geneva: World Health Organisation; 202028 August 2020.

8. Chiolero A, Buckeridge D. Glossary for public health surveillance in the age of data science. J Epidemiol Community Health. 2020;74(7):612-6.

9. PHE. Emergency Department Syndromic Surveillance System (EDSSS) Public Health England; 2021 [updated 27 January 2021. 19 August 2014:[Available from: https://www.gov.uk/government/collections/syndromic-surveillance-systems-and-

analyses\#emergency-department-syndromic-surveillance-system.

10. France Sp. Surveillance des urgences et des décès SurSaUD®: Santé publique France; [Available from: https://www.santepubliquefrance.fr/surveillance-syndromique-sursaudR/bulletins-sursaud-R-sos-medecins-oscour-mortalite.

11. Hughes HE, Edeghere O, O'Brien SJ, Vivancos R, Elliot AJ. Emergency department syndromic surveillance systems: a systematic review. BMC Public Health. 2020;20(1):1891.

12. Triple SP. Assessment of syndromic surveillance in Europe. Lancet. 2011;378(9806):1833-4.

13. Hughes HE, Morbey R, Hughes TC, Locker TE, Shannon T, Carmichael C, et al. Using an Emergency Department Syndromic Surveillance System to investigate the impact of extreme cold weather events. Public Health. 2014;128(7):628-35.

14. Elliot AJ, Hughes HE, Hughes TC, Locker TE, Shannon T, Heyworth J, et al. Establishing an emergency department syndromic surveillance system to support the London 2012 Olympic and Paralympic Games. Emergency medicine journal : EMJ. 2012;29(12):954-60.

15. Hughes HE, Hughes TC, Morbey R, Challen K, Oliver I, Smith GE, et al. Emergency department use during COVID-19 as described by syndromic surveillance. Emergency medicine journal : EMJ. 2020;37(10):600-4. 
medRxiv preprint doi: https://doi.org/10.1101/2021.08.19.21262303; this version posted August 21, 2021. The copyright holder for this preprint (which was not certified by peer review) is the author/funder, who has granted medRxiv a license to display the preprint in perpetuity.

It is made available under a CC-BY 4.0 International license .

16. Schranz M. Syndromic surveillance using emergency department data for the monitoring of unspecific acute gastrointestinal infections. Berlin, Germany: Charité - Universitätsmedizin 2019.

17. Greiner F, Brammen D, Erdmann B, Walcher F, Ziehm D. Vergleich von akuten respiratorischen Erkrankungen (ARE) in der Notaufnahme eines Schwerpunktversorgers mit Daten der ARE-Surveillance des Niedersächsischen Landesgesundheitsamtes zwischen 2013 und 2016. Gesundheitswesen (Bundesverband der Arzte des Offentlichen Gesundheitsdienstes (Germany)). 2017;79(04):A57.

18. Team S. Notaufnahme-Situationsreport. Robert Koch-Institut; 2021.

19. Boender TS, Greiner F, Kocher T, Schirrmeister W, Majeed RW, Bienzeisler J, et al. Inanspruchnahme deutscher Notaufnahmen während der COVID-19-Pandemie - der Notaufnahme-Situationsreport (SitRep). Epidemiologisches Bulletin. 2020(27):3--5.

20. Brammen D, Greiner F, Kulla M, Otto R, Schirrmeister W, Thun S, et al. Das AKTINNotaufnahmeregister - kontinuierlich aktuelle Daten aus der Akutmedizin. Medizinische Klinik Intensivmedizin und Notfallmedizin. 2020.

21. NoKeda - Notaufnahme-Kerndatenmodell für Public-Health-Surveillance und Versorgungsforschung [Internet]. 2020. Available from: https://art-decor.org/art-decor/decorproject--nokeda-\#.

22. Grafstein E, Bullard MJ, Warren D, Unger B, Group CNW. Revision of the Canadian Emergency Department Information System (CEDIS) Presenting Complaint List version 1.1. CJEM. 2008;10(2):151-73.

23. Christ M, Grossmann F, Winter D, Bingisser R, Platz E. Modern Triage in the Emergency Department. Dtsch Arztebl International. 2010;107(50):892-8.

24. Fitzner J, Qasmieh S, Mounts AW, Alexander B, Besselaar T, Briand S, et al. Revision of clinical case definitions: influenza-like illness and severe acute respiratory infection. Bull World Health Organ. 2018;96(2):122-8.

25. WHO. Global epidemiological surveillance standards for influenza: World Health Organisation; 2013.

26. Schilling J, Buda S, Fischer M, Goerlitz L, Grote U, Haas W, et al. Retrospektive Phaseneinteilung der COVID-19-Pandemie in Deutschland bis Februar 2021. Epidemiologisches Bulletin 2021(15):3--12.

27. Hohle M. Surveillance: An R package for the monitoring of infectious diseases. Computation Stat. 2007;22(4):571-82.

28. Goerlitz L, Dürrwald R, an der Heiden M, Buchholz U, Preuß U, Prahm K, et al. Erste Ergebnisse zum Verlauf der Grippewelle in der Saison 2019/20: Mit 11 Wochen vergleichsweise kürzere Dauer und eine moderate Anzahl an Influenza-bedingten Arztbesuchen. Epidemiologisches Bulletin. 2020;2020(16):3--6.

29. Emborg H-D, Carnahan A, Bragstad K, Trebbien R, Brytting M, Hungnes O, et al. Abrupt termination of the 2019/20 influenza season following preventive measures against COVID-19 in Denmark, Norway and Sweden. Eurosurveillance. 2021;26(22):2001160.

30. Adlhoch C, Mook P, Lamb F, Ferland L, Melidou A, Amato-Gauci AJ, et al. Very little influenza in the WHO European Region during the 2020/21 season, weeks 402020 to 82021. Eurosurveillance. 2021;26(11):2100221.

31. Coronavirus Disease 2019 (COVID-19) Weekly Situation Report from the Robert Koch Institute: Calendar week 17/2021. Rober Koch Institute.

32. Maharaj AS, Parker J, Hopkins JP, Gournis E, Bogoch, II, Rader B, et al. The effect of seasonal respiratory virus transmission on syndromic surveillance for COVID-19 in Ontario, Canada. Lancet Infect Dis. 2021;21(5):593-4.

33. Slagman A, Behringer W, Greiner F, Klein M, Weismann D, Erdmann B, et al. Medical Emergencies During the COVID-19 Pandemic. Deutsches Arzteblatt international. 2020;117(3334):545-52. 
medRxiv preprint doi: https://doi.org/10.1101/2021.08.19.21262303; this version posted August 21, 2021. The copyright holder for this preprint (which was not certified by peer review) is the author/funder, who has granted medRxiv a license to display the preprint in perpetuity.

It is made available under a CC-BY 4.0 International license .

34. Kapsner LA, Kampf MO, Seuchter SA, Gruendner J, Gulden C, Mate S, et al. Reduced Rate of Inpatient Hospital Admissions in 18 German University Hospitals During the COVID-19 Lockdown. Frontiers in Public Health. 2021;8(1018).

35. Mantica G, Riccardi N, Terrone C, Gratarola A. Non-COVID-19 visits to emergency departments during the pandemic: the impact of fear. Public Health. 2020;183:40-1.

36. Wyatt S, Mohammed MA, Fisher E, McConkey R, Spilsbury P. Impact of the SARS-CoV2 pandemic and associated lockdown measures on attendances at emergency departments in English hospitals: a retrospective database study. The Lancet Regional Health - Europe. 2021:100034.

37. Hartnett KP, Kite-Powell A, DeVies J, Coletta MA, Boehmer TK, Adjemian J, et al. Impact of the COVID-19 Pandemic on Emergency Department Visits - United States, January 1, 2019May 30, 2020. MMWR Morb Mortal Wkly Rep. 2020;69(23):699-704.

38. Mockel M, Searle J, Muller R, Slagman A, Storchmann H, Oestereich P, et al. Chief complaints in medical emergencies: do they relate to underlying disease and outcome? The Charité Emergency Medicine Study (CHARITEM). European journal of emergency medicine : official journal of the European Society for Emergency Medicine. 2013;20(2):103-8.

39. German RR, Lee LM, Horan JM, Milstein RL, Pertowski CA, Waller MN, et al. Updated guidelines for evaluating public health surveillance systems: recommendations from the Guidelines Working Group. MMWR Recomm Rep. 2001;50(RR-13):1-35; quiz CE1-7.

40. Elliot AJ, Harcourt SE, Hughes HE, Loveridge P, Morbey RA, Smith S, et al. The COVID19 pandemic: a new challenge for syndromic surveillance. Epidemiol Infect. 2020;148:e122.

41. Buchholz U, Buda S, Prahm K, Preuß U, Streib V, Haas W. GrippeWeb-Wochenbericht. Robert Koch-Institut; 2021. p. 4. 
medRxiv preprint doi: https://doi.org/10.1101/2021.08.19.21262303; this version posted August 21, 2021. The copyright holder for this preprint (which was not certified by peer review) is the author/funder, who has granted medRxiv a license to display the preprint in perpetuity.

It is made available under a CC-BY 4.0 International license.

\section{Additional information}

\section{$\underline{\text { Author contributions }}$}

LG, MS and TSB coordinated the ESEG-project and established the surveillance using emergency department data at RKI. TSB developed the study design, performed the data analysis and wrote the manuscript. FG and RZ ensured coordinated data sourcing from the AKTIN and ESEG part respectively. TK and BW ensured data provision and data quality, under supervision of AU. WC developed the case definitions, supported by TK, MS, BW, MD and SB who provided input on the methods, development and interpretation of the work. All authors critically revised the manuscript and approved its final version.

\section{$\underline{\text { Conflict of interest statement }}$}

None declared.

Funding

The Robert Koch Institute is an Institute within the portfolio of the Federal Ministry of Health. This work was funded by the Innovation Committee of the Federal Joint Committee (Innovationsfonds des Gemeinsamen Bundesausschusses, G-BA) [ESEG project, grant number 01VSF17034]. The implementation and operation of the AKTIN - Emergency Department Data Registry is funded by the Federal Ministry of Education and Research.

\section{Data statement}

The aggregated data of the attendances and cases (ARI, SARI, ILI, RSV, COVID-19) by week used for the analysis, will be provided.

\section{$\underline{\text { Acknowledgements }}$}

We are very grateful for all emergency departments in the AKTIN and ESEG networks, who contributed to the establishment of the emergency department surveillance in Germany, and shared their data. 
medRxiv preprint doi: https://doi.org/10.1101/2021.08.19.21262303; this version posted August 21, 2021. The copyright holder for this preprint (which was not certified by peer review) is the author/funder, who has granted medRxiv a license to display the preprint in perpetuity.

It is made available under a CC-BY 4.0 International license.

Table 1. Summary of total emergency department attendances, between 6 March 2017 (week 10-2017) up to and including 13 March 2021 (week 10-2021), for the full observation period, and stratified for the time before and during the COVID-19 pandemic.

\begin{tabular}{|c|c|c|c|}
\hline Period (weeks) & $10 / 2017-09 / 2020$ & $10 / 2020-10 / 2021$ & Total \\
\hline Attendances & $\mathrm{N}=1,082,850$ & $\mathrm{~N}=290,108$ & $\mathrm{~N}=1,372,958$ \\
\hline \multicolumn{4}{|l|}{ Age (in years) } \\
\hline $0-2$ & $56,356(5.2 \%)$ & $18,682(6.4 \%)$ & $75,038(5.5 \%)$ \\
\hline $3-4$ & 40,817 (3.8\%) & $7,209(2.5 \%)$ & $48,026(3.5 \%)$ \\
\hline $5-9$ & $56,330(5.2 \%)$ & $11,479(4.0 \%)$ & 67,809 (4.9\%) \\
\hline $10-14$ & $43,080(4.0 \%)$ & 9,383 (3.2\%) & $52,463(3.8 \%)$ \\
\hline $15-19$ & $49,574(4.6 \%)$ & 11,580 (4.0\%) & $61,154(4.5 \%)$ \\
\hline $20-39$ & $183,765(17.0 \%)$ & $47,380(16.3 \%)$ & 231,145 (16.8\%) \\
\hline $40-59$ & $269,240(24.9 \%)$ & 75,096 (25.9\%) & $344,336(25.1 \%)$ \\
\hline $60-79$ & $227,639(21.0 \%)$ & $65,311(22.5 \%)$ & 292,950 (21.3\%) \\
\hline $80+$ & $156,049(14.4 \%)$ & 43,988 (15.2\%) & 200,037 (14.6\%) \\
\hline \multicolumn{4}{|l|}{ Sex } \\
\hline Female & $524,790(48.5 \%)$ & $140,161(48.3 \%)$ & $664,951(48.4 \%)$ \\
\hline Male & $557,971(51.5 \%)$ & 149,937 (51.7\%) & $707,908(51.6 \%)$ \\
\hline Other & $89(0.0 \%)$ & $10(0.0 \%)$ & $99(0.0 \%)$ \\
\hline \multicolumn{4}{|l|}{ Triage } \\
\hline Immediate & $11,494(1.1 \%)$ & 3,795 (1.3\%) & $15,289(1.1 \%)$ \\
\hline Very Urgent & $140,416(13.0 \%)$ & 42,924 (14.8\%) & $183,340(13.4 \%)$ \\
\hline Urgent & $394,089(36.4 \%)$ & $116,371(40.1 \%)$ & $510,460(37.2 \%)$ \\
\hline Standard & $442,466(40.9 \%)$ & $102,638(35.4 \%)$ & 545,104 (39.7\%) \\
\hline Non-urgent & $47,274(4.4 \%)$ & $13,041(4.5 \%)$ & 60,315 (4.4\%) \\
\hline Missing & $47,111(4.4 \%)$ & 11,339 (3.9\%) & $58,450(4.3 \%)$ \\
\hline \multicolumn{4}{|l|}{ Transport } \\
\hline Patient transport & $25,134(2.3 \%)$ & $6,289(2.2 \%)$ & $31,423(2.3 \%)$ \\
\hline Ambulance & 102,827 (9.5\%) & 42,768 (14.7\%) & 145,595 (10.6\%) \\
\hline Emergency ambulance & $55,512(5.1 \%)$ & $16,889(5.8 \%)$ & 72,401 (5.3\%) \\
\hline Helicopter & $30,092(2.8 \%)$ & $274(0.1 \%)$ & $30,366(2.2 \%)$ \\
\hline Other & $170,045(15.7 \%)$ & $65,628(22.6 \%)$ & $235673(17.2 \%)$ \\
\hline Missing & $699,240(64.6 \%)$ & $158,260(54.6 \%)$ & $857500(62.5 \%)$ \\
\hline \multicolumn{4}{|l|}{ Referral } \\
\hline Hospital/transfer & $15,561(1.4 \%)$ & $5,022(1.7 \%)$ & $20,583(1.5 \%)$ \\
\hline $\begin{array}{l}\text { Ambulatory emergency } \\
\text { service outside hospital }\end{array}$ & $16,636(1.5 \%)$ & $4,294(1.5 \%)$ & $20,930(1.5 \%)$ \\
\hline $\begin{array}{l}\text { Ambulatory emergency } \\
\text { practice within hospital }\end{array}$ & $10,196(0.9 \%)$ & $2,354(0.8 \%)$ & $12,550(0.9 \%)$ \\
\hline Not referred by physician & $258,764(23.9 \%)$ & $89,385(30.8 \%)$ & $348,149(25.4 \%)$ \\
\hline Other & $133,834(12.4 \%)$ & $17,805(6.1 \%)$ & $151,639(11.0 \%)$ \\
\hline Emergency service & $191,286(17.7 \%)$ & $65,478(22.6 \%)$ & $256,764(18.7 \%)$ \\
\hline Medical practitioner & $54,711(5.1 \%)$ & $16,092(5.5 \%)$ & $70,803(5.2 \%)$ \\
\hline Missing & $401,862(37.1 \%)$ & $89,678(30.9 \%)$ & $491,540(35.8 \%)$ \\
\hline
\end{tabular}


medRxiv preprint doi: https://doi.org/10.1101/2021.08.19.21262303; this version posted August 21, 2021. The copyright holder for this preprint (which was not certified by peer review) is the author/funder, who has granted medRxiv a license to display the preprint in perpetuity.

It is made available under a CC-BY 4.0 International license.

Table 1. continued.

\section{Disposition}

Death

Discharge against medical

advice

Treatment discontinued by

patient

Discharge to home

Release for further

treatment by a physician

No physician contact

Inpatient admission -

operational unit

Inpatient admission -

monitoring unit

Inpatient admission -

regular ward

External transfer

Other

Missing

$\begin{array}{rrr}5,788(0.5 \%) & 109(0.0 \%) & 5,897(0.4 \%) \\ 6,611(0.6 \%) & 2,170(0.7 \%) & 8,781(0.6 \%) \\ 2,406(0.2 \%) & 589(0.2 \%) & 2,995(0.2 \%) \\ 119,779(11.1 \%) & 42,374(14.6 \%) & 162,153(11.8 \%) \\ 15,343(1.4 \%) & 4,480(1.5 \%) & 19,823(1.4 \%) \\ & & \\ 1,774(0.2 \%) & 212(0.1 \%) & 1,986(0.1 \%) \\ 3,577(0.3 \%) & 1,482(0.5 \%) & 5,059(0.4 \%) \\ & & \\ 18,495(1.7 \%) & 7,322(2.5 \%) & 25,817(1.9 \%) \\ 73,260(6.8 \%) & 26,125(9.0 \%) & 99,385(7.2 \%) \\ 31,770(2.9 \%) & & \\ 42,173(3.9 \%) & 820(0.3 \%) & 32,590(2.4 \%) \\ 761,874(70.4 \%) & 204,350(70.5 \%) & 42,248(3.1 \%) \\ & & 966,224(70.4 \%)\end{array}$




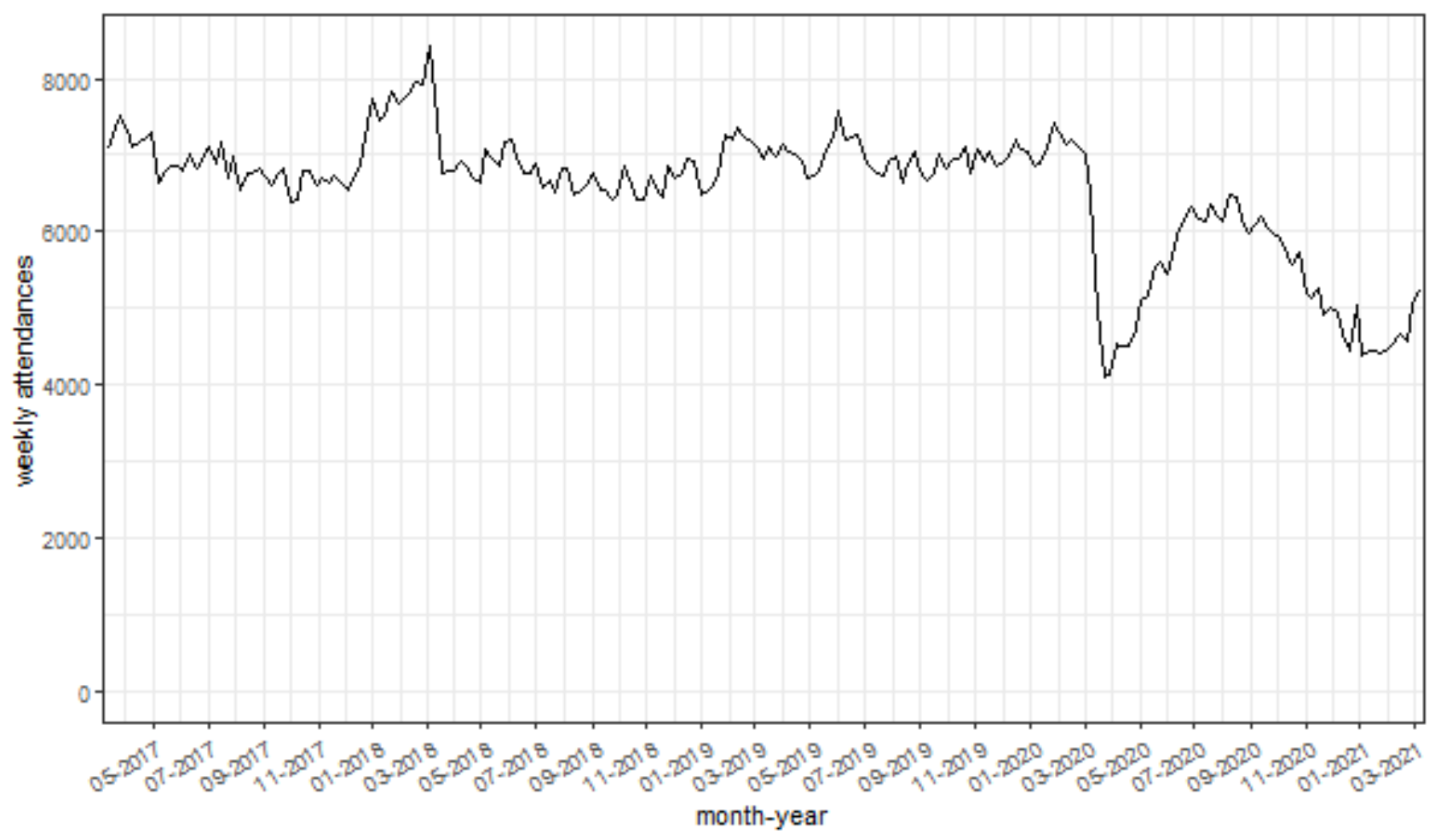

Figure 1. Weekly emergency department attendances, between 6 March 2017 (week 102017) up to and including 13 March 2021 (week 10-2021). 


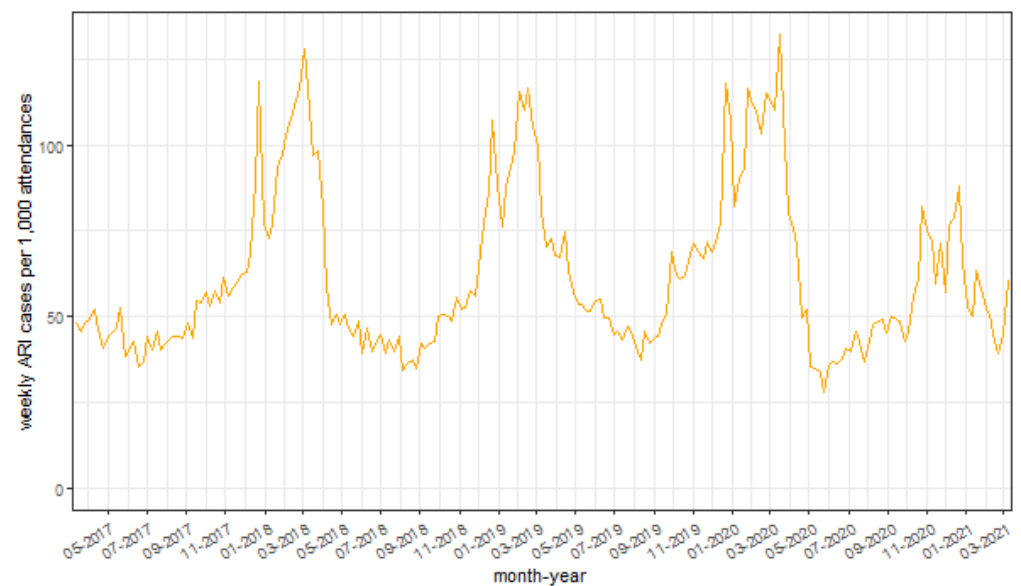

Figure 2A: acute respiratory illness (ARI)

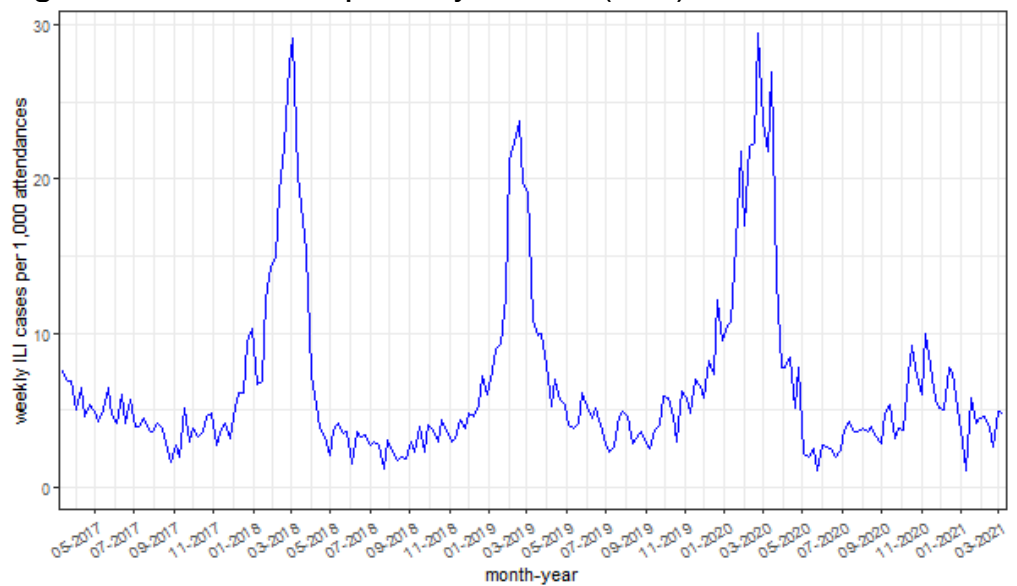

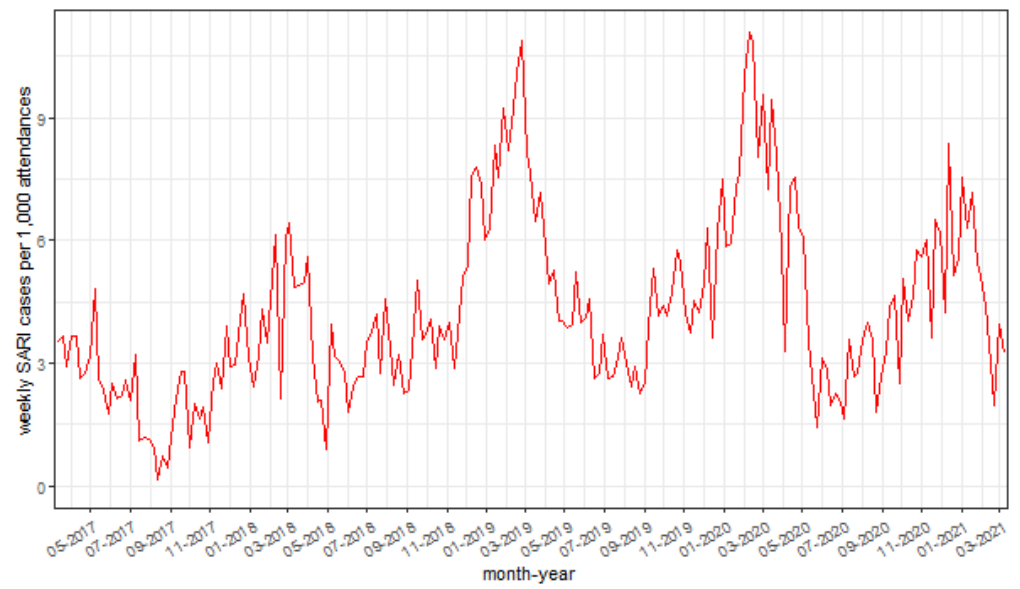

Figure 2B: severe acute respiratory illness (SARI)

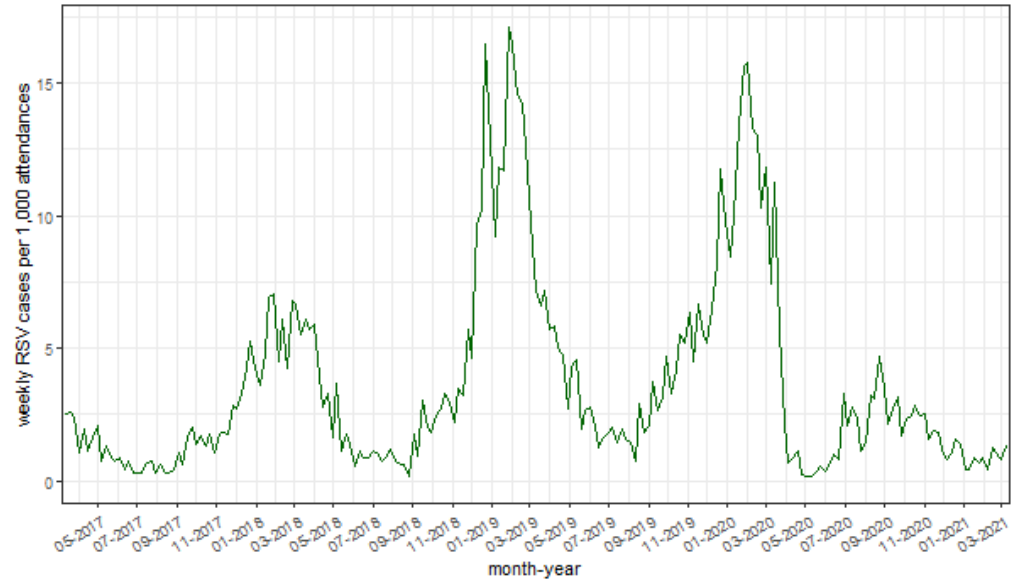

Figure 2C: influenza-like-illness (ILI)

Figure 2D: respiratory syncytial virus (RSV)

Figure 2. Weekly case counts (ARI, SARI, ILI, RSV) per 1,000 emergency department attendances, between 6 March 2017 and 13 March 2021. 
Decomposition of additive time series

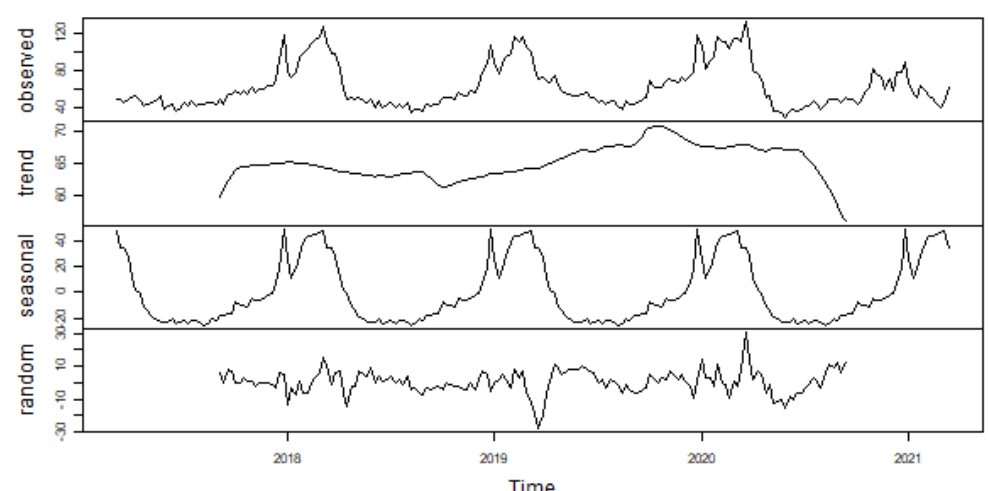

Figure 3A: acute respiratory illness (ARI)

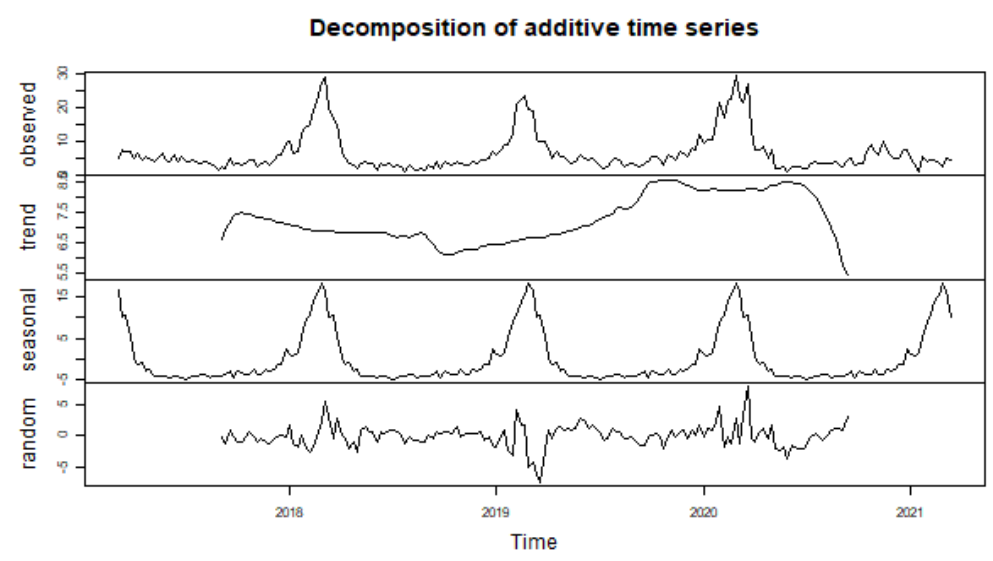

Decomposition of additive time series

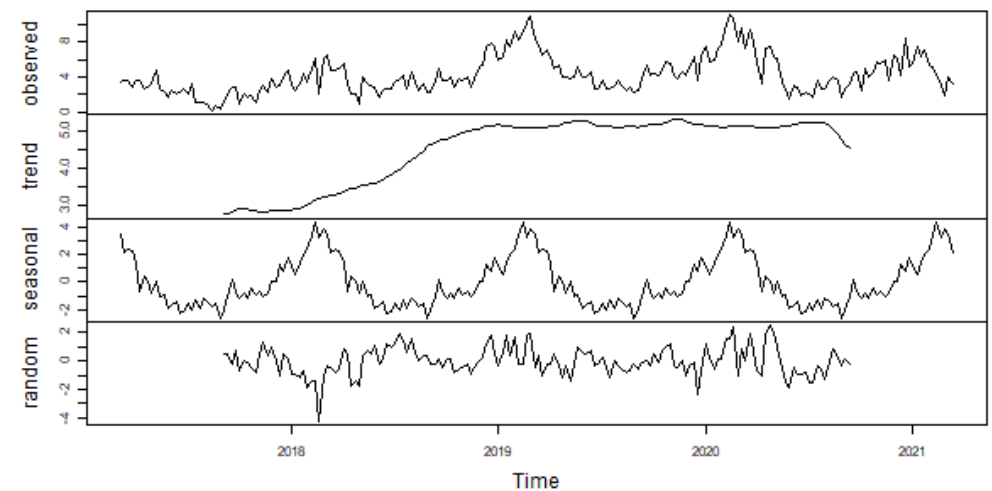

Figure 3B: severe of acute respiratory illness (SARI)

Decomposition of additive time series

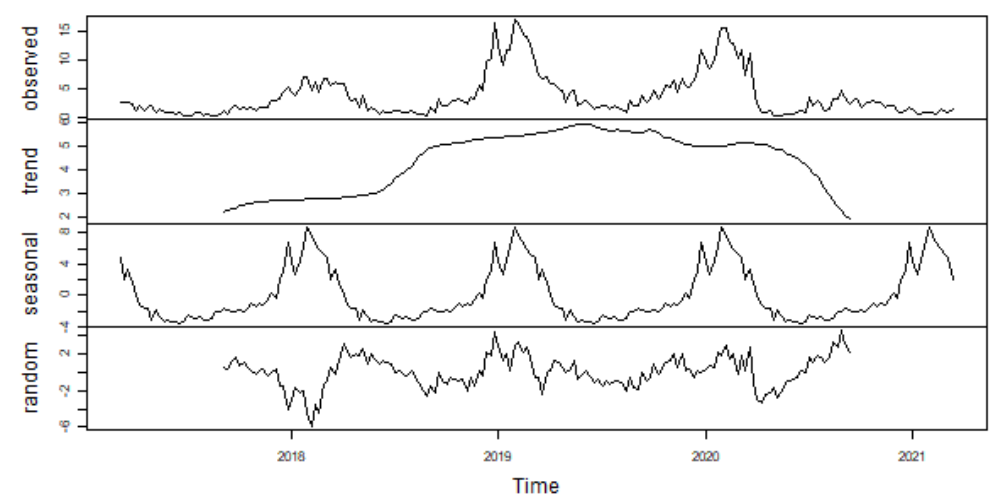

Figure 3C: influenza-like-illness (ILI)

Figure 3D: respiratory syncytial virus (RSV)

Figure 3. Decomposed time series of the weekly case counts, per 1,000 emergency department attendances, between 6 March 2017 and 13 March 2021. 


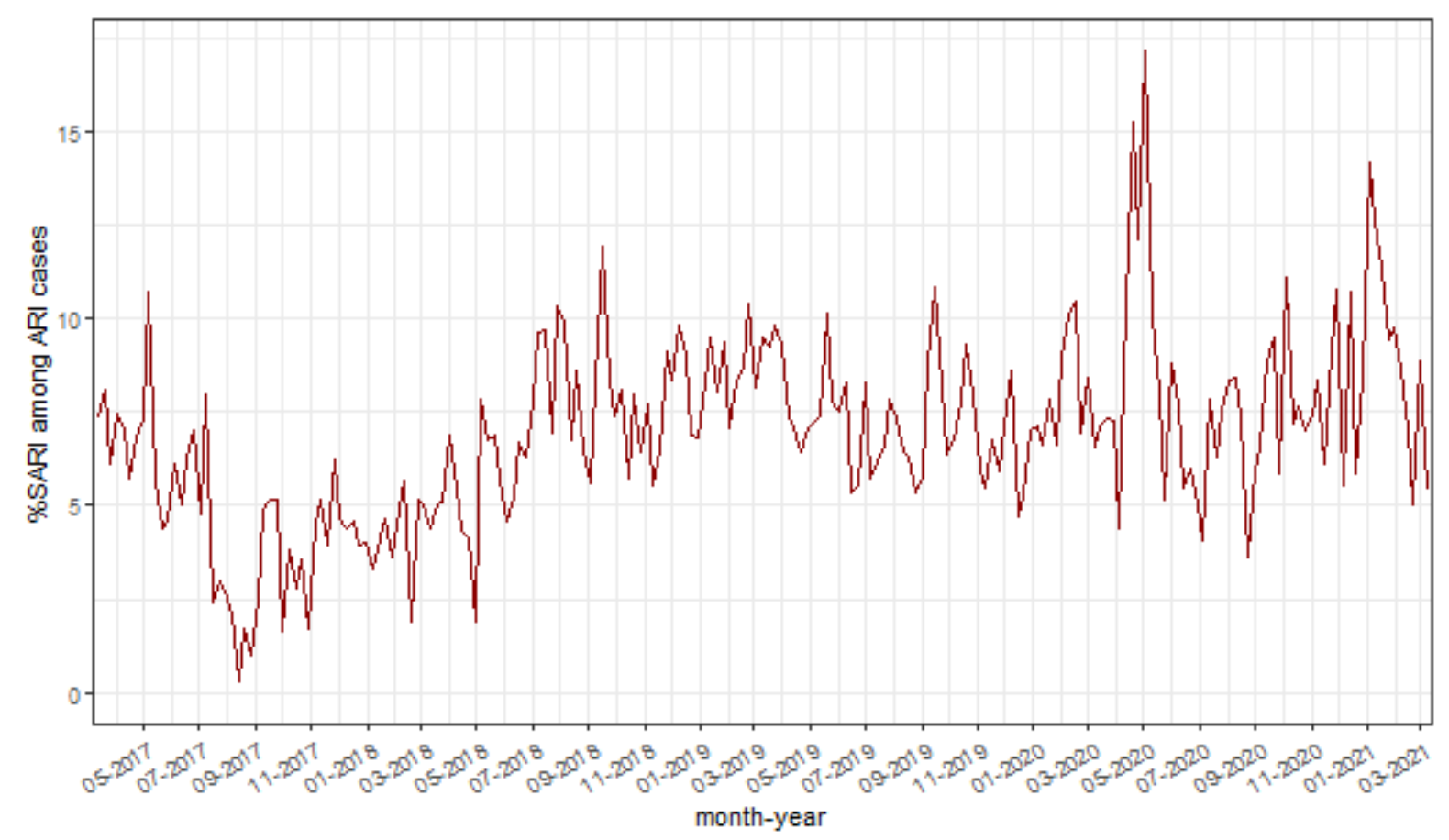

Figure 4. Proportion (\%) of severe acute respiratory illness (SARI) cases among cases of acute respiratory illness (ARI), between 6 March and including 13 March 2021.

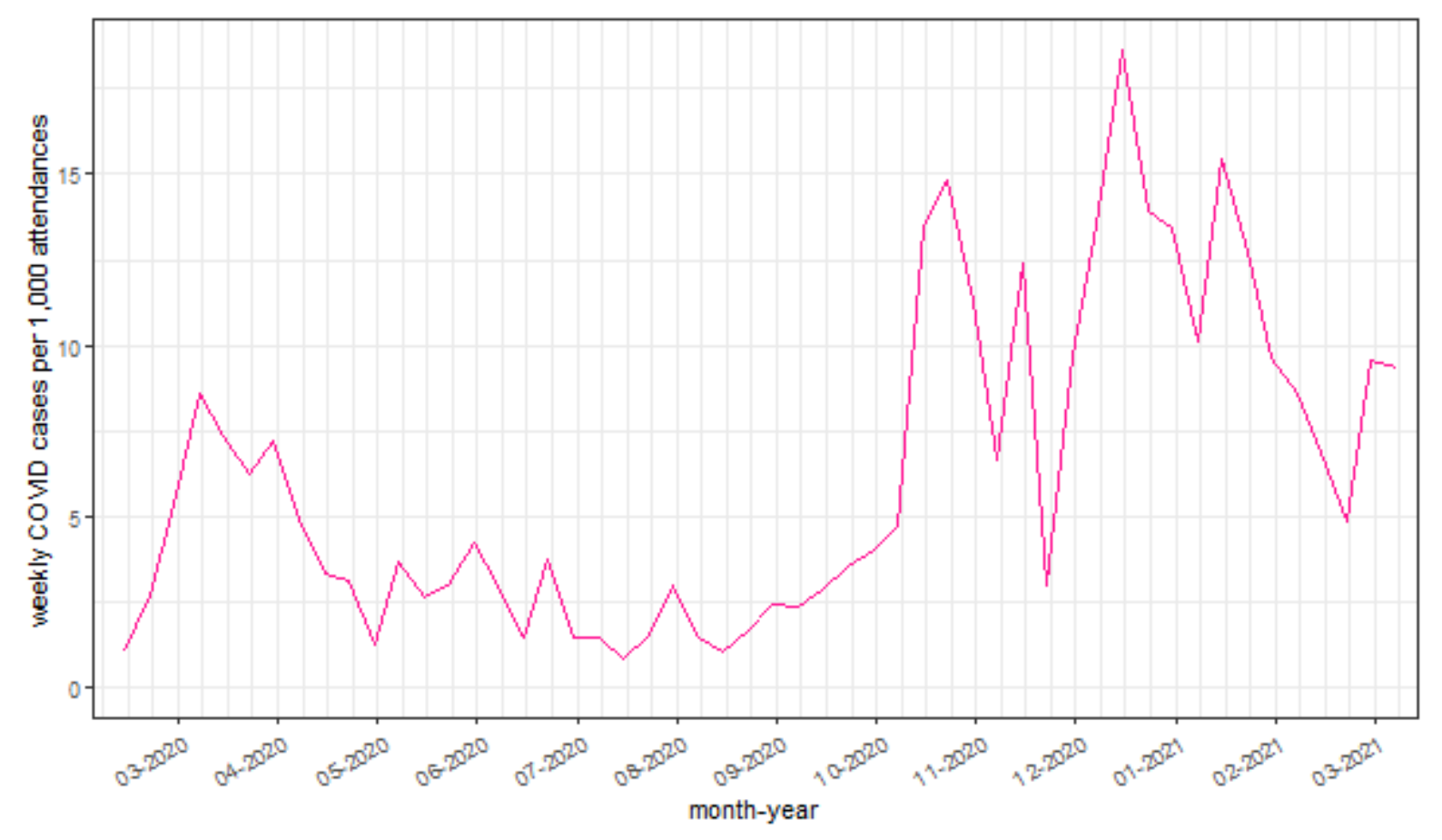

Figure 5. Summary of COVID-19 cases per week, per 1,000 emergency department attendances, between 6 March 2020 and 13 March 2021. 